\title{
Chapter 6 \\ The National Popular Vote Plan: \\ A Brilliant Idea or a Dead-on-Arrival \\ Delusion?
}

\begin{abstract}
Should the country replace the Electoral College-based presidential election system with a direct popular election of a President? In the United States, many people believe it should though numerous attempts to do it de jure, by amending the Constitution, have failed. This chapter attempts to describe the National Popular Vote plan aimed at introducing a direct popular election of a President de facto, without amending the Constitution. This chapter presents the arguments that suggest that the plan may violate the Supreme Court decisions relating to the manner in which the plan proposes to award electoral votes in state-signatories to the plan. That is, this manner may violate the Equal Protection Clause from the Fourteenth Amendment. This chapter provides numerical examples suggesting that the claims of the NPV plan originators that the plan would encourage the candidates to chase every vote throughout the country are no more than wishful thinking. The reasoning presented in the chapter may help the reader decide whether the plan is an "ingenious" idea, or a dead-on-arrival, unconstitutional proposal.
\end{abstract}

Keywords Appointing non-voted electors - Equal Protection Clause - Impairment Clause - National Popular Vote plan - National contest - "One person, one vote" principle $\cdot$ Recount $\cdot$ Weighted voting games

Should the country replace the Electoral College-based presidential election system with a direct popular election of a President?

In the United States, many people believe it should. Numerous attempts to do away with the current Electoral College-based election system by replacing it with a direct popular presidential election de jure, by amending the Constitution, have been undertaken over the years. However, all these attempts, including those from 1968 to 1970 and, especially, those of 1969 , the closest to success, have failed.

In the aftermath of the 2000 election, Professor Robert Bennett proposed a new approach to changing the existing election system. He proposed that interested states could use one of the key provisions of the Constitution that gives the state legislatures the plenary power to appoint state presidential electors in any manner 
they want [55]. A similar approach was proposed by Professors Akhil Amar and Vikram Amar [56] at around the same time. Later, Dr. John Koza proposed yet another approach to introducing a direct popular presidential election de facto, without amending the Constitution. His approach is, in fact, a slight modification of the two above-mentioned approaches, and it has been formulated as a plan called the National Popular Vote (NPV) plan [5]. This new plan gave birth to the movement called the National Popular Vote, in progress since 2006.

The National Popular Vote plan is a phenomenon deserving special attention. No other plan for changing the current election system has ever drawn so much attention from the media and received ardent support from a part of it. The idea of the plan, its constitutionality, and its deficiencies, along with the reasons this plan has become a national movement, are the subject of this chapter.

This chapter attempts to describe the National Popular Vote plan and presents the arguments that suggest that the plan may violate the Supreme Court decisions relating to the manner in which the plan proposes to award electoral votes of state-signatories to the plan. That is, this manner may violate the Equal Protection Clause from the Fourteenth Amendment. This chapter provides numerical examples suggesting that the claims of the NPV plan originators that the plan would force the candidates to chase every vote throughout the country are no more than wishful thinking. The reasoning presented in the chapter may help the reader decide whether the plan is an "ingenious" idea, or a dead-on-arrival, unconstitutional proposal.

\subsection{The National Popular Vote Plan: What It Is, and Who Supports It}

The idea of the NPV plan is to build a coalition (or a compact) of the states and D.C. controlling at least 270 electoral votes combined that would agree to award their electoral votes collectively. According to the plan, a pair of presidential and vice-presidential candidates whose slates of state and D.C. electors receive the most votes nationwide would be awarded all the electoral votes controlled by the coalition, i.e., at least 270 electoral votes. Under the plan, a majority of all the electoral votes that are in play in the election is to be awarded to the pair of the candidates preferred by the coalition

(a) despite the will of voters in the state-subscribers to the plan, and

(b) with no attention to the states that do not subscribe to the plan and favor a pair of the candidates different from the pair preferred by the coalition.

Thus, the NPV plan would determine the winning pair of presidential and vice-presidential candidates based on the tally of votes received by all the electors nationwide rather than on the state-by-state tally of state and D.C. electoral votes. Under the NPV plan, currently, any 11-20 states and D.C. that control at least 270 electoral votes combined may make the choice of all the other states irrelevant in 
choosing a President, no matter whether these other states subscribe to the NPV plan or not.

Moreover, the coalition may eventually make irrelevant the choice of all the 50 states and D.C. Indeed, let D.C. and a group of states that together with D.C. form a compact controlling at least 270 electoral votes combined subscribe to the NPV plan. (As is known, D.C. has already become a signatory to the NPV plan.) Also, let presidential candidate A lose to one of the other, say, two participating candidates in each and every state and in D.C., but let the slates of candidate A's electors receive a plurality of all the votes cast. Then, according to the NPV election rules, candidate A is elected President (in the Electoral College).

When one argues that as part of the NPV compact, the 11 largest states may make irrelevant the will of the voters in the rest of the country, proponents of the NPV plan often object that this may happen under the current rules. While the objection is formally correct, there is a substantial difference between the NPV election rules and those of the current system. Under the current rules, the 11 largest states may decide the outcome only if a candidate wins in all of them. In contrast, the 11 states as a part of the compact may let a candidate lose in all the states and in D.C. and still be elected President.

Though many states would lose their voice under the NPV plan, state legislatures of several states support this plan anyway. According to the NPV movement website, the plan is either pending or at least has been introduced in all the 50 states, and ten statesMaryland, Illinois, Hawaii, Rhode Island, New York, Massachusetts, Vermont, California, Washington, and New Jersey - and D.C. have already signed it into law.

One may only wonder why this plan has become so popular among the state legislators who would not support a constitutional amendment to replace the current election system with direct popular presidential elections.

Several reasons seem to explain this phenomenon.

1. The chances of the introduction of any direct popular presidential election in the country de jure seem to be slim. All the 27 of the adopted amendments were initiated by two-thirds of both chambers of Congress. (The initiation of an amendment by a national convention called by Congress at the request of two-thirds of the legislators of all the states, has never been used.) Except for Amendment 21, ratified by conventions in three-fourths of all the states, all the amendments were ratified by the legislatures of three-fourths of all the states [19]. Thus, the implementation of both parts of the process of amending the Constitution is difficult and unpredictable.

In contrast, the promises of the NPV originators and backers look like a simple solution to a long existing problem. Moreover, legislators in many states look at the NPV "together" with numerous NPV lobbyists, who actively promote this impression. Today, the National Popular Vote movement, which promotes the NPV plan, is well organized and has lobbyists "working" with every state legislature in the country. 
2. The NPV plan enjoys a strong support from many influential media members, who can easily publish essays in support of the NPV plan in the most popular national newspapers. The NPV movement has managed to convince prominent Americans to serve as national spokesmen for the plan. Due to their popularity and connections in society, these people are welcome on almost any national TV programs, where they promote the NPV plan without any serious opposition. In contrast, the same newspapers that welcome essays supporting the NPV plan are quite reluctant to publish articles containing any serious analysis of the plan. Certainly, there is no chance to address the weak points of the plan and its constitutionality on the same national TV programs that easily give air time to the NPV promoters.

3. The NPV originators and promoters have managed to keep many Americans very much taken with the claim that the NPV plan can make every vote equal without eliminating the Electoral College and without amending the Constitution. Though the plan first surfaced in 2006, there has never been a national debate about the NPV, so many of those who take the above claim as a true statement remain unaware of the NPV origins, deficiencies, and real features. The same people who blindly support the NPV plan are unaware of the peculiarities and features of the current election system either, as well as of any other alternatives to it. Thus, the seeds of "wishful thinking" planted by the NPV originators and backers fall on fertile soil. This promotional strategy, enhanced by the support of a part of the media, seems to have succeeded, which helps the NPV originators claim an overwhelming enthusiasm for their plan in every state in the country.

The NPV movement conducts its own polls, and both the questions asked in the polls and the manner in which the polls are conducted and processed are under control of the movement. One of the questions asked, which can be found on the NPV web site, is: "How do you think we should elect the President: Should it be the candidate who gets the most votes in all 50 states, or the current electoral college system?"

The NPV movement claims that an overwhelming majority of respondents to the polls choose the first option, which well may be true. However, this does not mean that the same respondents would answer the question the same way if the first answer were, for instance, "The candidate who gets the most votes in 50 states, even if the candidate receives only a 15-20\% plurality and loses to her/his opponents in each of the 50 states and in the District of Columbia."

Such an outcome is possible under the NPV election rules, since under these rules multi-candidate races are likely to emerge [32]. Even if only three candidates participate in the race, as mentioned earlier in this chapter, the NPV election rules may make the election winner a candidate who has the support of as little as $34 \%$ of voting voters and who loses to the opponents in each of the 50 states and in D.C.

Ross Perot managed to garner support of almost $19 \%$ of voting voters in the 1992 election, even despite the fact that he suspended his campaign for several 
weeks in the course of the race. His result bears evidence that the NPV election rules may produce such an outcome in an election with three or more strong candidates in the race.

4. Many Americans are very much concerned with any inequality that may transpire in society in any form, and they welcome positive changes in the country. The NPV originators and proponents quite skillfully exploit both phenomena, by depicting their plan as a simple and doable solution to a long existing problem and by claiming that this solution will benefit every voter in the country.

They have even managed to "equate" the problems of the current election system with those of the "winner-take-all" method for awarding state electoral votes though the whole idea of the NPV plan cannot survive without this method or any similar one, prohibiting a state voter from favoring electors from slates of electors of different presidential candidates competing for state electoral votes. However, the "winner-take-all" method is no more than a particular though widespread method for awarding state electoral votes. It has never been mandatory for any state, and it is not part of the Constitution. The state legislature of any state can switch to any other method for awarding state electoral votes, for instance, to the Maine-like district method (see Sect. 2.4) or to any other method allowing state voters to favor electors from different slates of electors at any time. Such a move does not require any approval of Congress or passing a constitutional amendment to this end.

The listed reasons look like the major ones to explain why the NPV originators and proponents seem to have convinced many Americans that if adopted, the NPV plan would address and solve basic problems of the existing election system.

\subsection{The Equality of Votes Under the NPV Plan: What Is Real, and What Is Plausible}

The NPV promoters have successfully manipulated the concept of voter equality and even try to exploit the Supreme Court decisions in which the Court discusses the equality of votes of voting voters.

In the Court decisions that involve the equality of votes, the Supreme Court stated several times that (a) constitutionally, the equality of weights of votes is mandatory only within a state, and (b) this equality is not applicable to electing presidential electors. The inequality of weights of votes cast in different states in electing a President is part of the 1787 Great Compromise. The Founding Fathers agreed to this inequality to balance an unequal representation of the states in the House of Representatives in electing a President there.

The state legislators who believe that it is either time or an opportunity to change this balance do not seem to understand what their states really gain, and what they lose by subscribing to the NPV plan in the name of equality of votes (which are cast not for President or Vice President, but only for their electors). 
Since the NPV plan keeps the Electoral College, one can speak only about the equality of votes cast in different states and in D.C. for different slates of electors to represent the state and D.C. in the Electoral College. Only as long as each state and D.C. prohibit their voters from favoring electors from slates of electors of different presidential candidates competing there, can one consider votes cast for the slates of electors as those cast for presidential and vice-presidential candidates. Though every state may abandon this restriction, only assuming that no state does, can one speak about a direct popular election under the NPV election rules.

Assuming that this is the case, one should admit that under any direct popular election rules, including the NPV ones, every voting voter controls an equal "chunk" in the election result. For instance, if 200,000,000 voters voted in a presidential election, each voter would control the choice of 1/200,000,000 part of the next Presidency [1]. Would this mean that voting voters in any particular state are likely to benefit from such an "equality?" It depends on how strong the national contest is.

Indeed, let $60 \%$ of likely voters in the country a priori favor ticket A. If this is the case, the other $40 \%$ of likely voters will have no chance to affect the election outcome. As a result, the candidates do not need to care about this $40 \%$ minority votes and may decide not to address any issues that concern these voters. Despite the equal weight that every voting voter has throughout the country, the will of these $40 \%$ of the voters will not matter in the election. This may be the case even if these voters represent the will of overwhelming majorities in each of as many as, say, three-fourths of all the states and could have decided the election outcome under the current election rules. Moreover, if these preferences of the voters remain unchanged during a set of sequential presidential elections, an overwhelming majority of the states may not be able to change the election outcome for many years.

In contrast, under the existing presidential election system, these $40 \%$ of voters may even decide the election outcome.

Indeed, let 130 million votes be cast for tickets $\mathrm{A}, \mathrm{B}$, and $\mathrm{C}$ in an election. Let ticket A win in the states of California, New York, Texas, Florida, Pennsylvania, Ohio, Georgia, Missouri, Washington, Alabama, Connecticut, Arkansas, Delaware, and Wyoming. Further, let ticket A receive 60 million votes combined in these fourteen states, which currently control 249 electoral votes combined. Finally, let ticket A receive 18 million votes in D.C. and in the other 36 states combined.

Let ticket B win in D.C. and in each of the above 36 states by having received 30 million votes total, and let this ticket receive 9 million votes in the above 14 states total. Finally, let ticket $\mathrm{C}$ receive 5 million votes in the above 14 states and 8 million votes in D.C. and in the above 36 states total.

Since D.C. and the above 36 states control 289 electoral votes combined, ticket $\mathrm{B}$ wins the election having won in all these 37 jurisdictions and having won $30 \%$ of all the votes cast in the election. Ticket A loses the election with $60 \%$ of all the votes cast and having won only in 14 states, including all the four largest states.

Thus, this $40 \%$ of all the votes cast may decide the election outcome by winning in an overwhelming majority of the states and in D.C., even with these votes split between tickets $\mathrm{B}$ and $\mathrm{C}$. (One can easily assign particular numbers of votes from 
the above-indicated totals to favor each of the three tickets in each of the 50 states and in D.C. that would secure the victory to ticket B in D.C. and in each of the above 36 states.)

In the absence of a strong national contest, any direct popular election represents the "winner-take-all" principle on the national scale, no matter whether a majority or a plurality rule is to determine the election winner. The whole country becomes "safe" for ticket A in just the same way some states become "safe" under the current election rules. If this is the case, the "equality" of votes throughout the country can be understood only in the sense of the inability of both an individual voter from a $60 \%$ majority and an individual voter from the $40 \%$ minority to affect the election outcome.

Certainly, neither the NPV originators and proponents nor their lobbyists communicate this simple reasoning to state legislatures and to the American people. Nor do they communicate to them how different the value of votes would be under the NPV election rules. In particular, they do not communicate how different this value would be for the small states in the Electoral College in a direct popular election, regardless of the equality of weights of all the votes.

Consider the 2008 election in which only 6,112,148 votes were cast in Alaska, Delaware, Hawaii, Maine, Montana, New Hampshire, Nevada, North Dakota, Rhode Island, South Dakota, Vermont, Wyoming and D.C. combined. The votes cast in these thirteen members of the Union with three and four electoral votes each constituted about $4.6 \%$ of the total of $131,463,122$ votes cast. A majority of voting voters in these thirteen members of the Union combined favored Barack Obama, who won the election with a margin of 9,549,105 votes [31].

How would the election outcome have changed under the NPV election rules if all the voters in the above twelve states and D.C. had favored John McCain or anyone else? It would not have changed. Thus, had the distribution of the votes cast in the other 38 states been the same as it was in the 2008 election, the votes cast in D.C. and in the twelve states would not have affected the election outcome, i.e., would have been irrelevant in the 2008 election. This would have been true both under the NPV election rules and under any direct popular elections, despite the fact that all the votes would have had the same weight, i.e., would have been equal [1].

This illustrative example casts doubts that the desired equality of votes, which the NPV plan originators aspire to bring to presidential elections, can substantially change the treatment of the small states. Unless the national contest is very close, small states cannot count on the attention of the major party candidates in the course of election campaigns, even if these states are closely contested. It is clear that the "winner-take-all" method, the major "scapegoat" the NPV originators and promoters blame, has nothing to do with this phenomenon.

The status of the above twelve states and D.C. is remarkably different under the rules of the current election system. Indeed, these thirteen members of the Union governed 45 electoral votes in the 2008 election. Had they been closely contested in that election, they all would have been "battlegrounds" for both major party candidates, no matter how close the national contest would have been. 
However, the author would like to make it clear that all this does not prove one of the underlying claims of the NPV plan wrong. Indeed, it does not prove that under the NPV rules, presidential candidates may not care about the votes in the small states as much as they will about the votes in densely populated parts of the country. The presented reasoning only provides evidence that the claim looks counterintuitive. It is incumbent on the NPV originators and proponents either to back up their claim or to agree that this claim has no grounds and represents no more than a plausible belief of its authors.

\subsection{The "Achilles' Heel" of the NPV Plan}

The NPV plan proponents and lobbyists may succeed in subscribing to the plan several states that control at least 270 electoral votes combined. If they do, would this mean that the objections of the other states to the plan and their refusal to join it are irrelevant?

Not necessarily, though at first glance, this looks like the case. Indeed, there is a chance that the NPV plan will be considered by the Supreme Court, and the Court may find the NPV plan unconstitutional in the first place.

Even if the plan were not found unconstitutional, some states may opt not to subscribe to this plan, and a lot depends on whether (and how) the states disagreeing with the NPV plan decide to react. There may be states that will opt not to join the NPV plan while deciding to continue to "supply" the NPV signatory states with votes cast for slates of state presidential electors. If all the other states join the plan, then the NPV election rules will govern presidential elections, and this can last as long as state-signatories to the plan continue to control at least 270 electoral votes combined. But even if this were the case, any state-signatory to the NPV plan, where this plan is a state law, may repeal this law before any election to come.

The picture would be completely different if at least one state opted to actively oppose the NPV plan by not providing its votes for the so-called "national tally," which the NPV plan would use to determine the election winner. The NPV election rules read that should this happen, only the remaining states and D.C.- that continue to vote for slates of electors according to the "winner-take-all" principlewould be eligible to participate in determining the election outcome [5].

Excluding a state that held a legitimate statewide election to award state electoral votes from the national election would create both moral and legal problems for the NPV plan.

Indeed, if this were the case, the NPV would not be able to claim that it awards a majority of all the electoral votes that are in play in the election on behalf of the nation or according to the popular vote results. The tally of votes (cast for presidential electors!) would not include votes from the states (legitimately) cast for electors from the slates of electors of different presidential candidates competing there. Excluding these votes would be un-American and would obliterate the underlying intent of the NPV plan to make every vote count. 
The result of such a decision of the disagreeing state (or states) may encourage a law suit, which may be filed by the state (or states) excluded. Such a law suit would once again put the constitutionality of the NPV rules into question with a quite predictable outcome.

Certainly, if more than one state became excluded from deciding the outcome of the election, the above law suit would look even stronger. However, the most unfavorable development for the NPV plan would take place if only state-signatories to the plan supported it and voted for electors from only one slate of electors of presidential candidates competing in the state, and these states formed a minority of all the states. Indeed, if this were the case, a majority of all the votes cast could turn out to be cast outside the state-signatories, i.e., in the states that oppose the NPV plan and do not follow the above voting restriction. Then according to the NPV election rules, this majority of the votes cast would be excluded from the tally determining the fate of a majority of the electoral votes. Moreover, one cannot rule out that in this case, a person who is to be declared President under the NPV election rules and a person who would have been declared President under the Electoral College rules would be different persons.

Under this scenario, the Supreme Court would face a tough choice to determine which composition of the Electoral College is legitimate, the one formed according to the NPV election rules or the one formed according to the rules that have been in force for more than 220 years [57, 58].

The protesting states, opposing the NPV plan, do not need to sign any "anti-compact" agreement to counteract the NPV plan. However, they may collectively appeal to the Supreme Court on their exclusion from making a decision on the election outcome. All they need to do to make the case is to switch from the "winner-take-all" method for awarding state electoral votes to any other method, which does not let the state-signatories to the NPV plan count the votes cast in the opposing states in the tally determining the election outcome under the NPV plan.

Certainly, this self-defense strategy may come into play only if the Supreme Court finds the NPV plan to be constitutional.

The NPV originators apparently believe that once a "compact" of states has been formed, the states opposing this plan will have no choice other than to follow the NPV election rules. They also seem to believe that the states, especially the "safe" states, will easily surrender their current Electoral College benefits.

However, the opposing states can turn the plenary right of every state to choose a manner of appointing its presidential electors - which ironically underlies the NPVinto the "Achilles' heel" of this plan [57, 33].

The state legislatures of the opposing states may allow voters to favor individual electors of their choice from any slate of state electors. The top vote-getters would then represent the state in the Electoral College, and all the votes cast would remain legitimate, since they were cast for presidential electors, in line with the Constitution. By doing so, the legislature of each opposing state can make impossible to use the tally of votes legitimately cast in their state as a part of the NPV tally. The NPV tally, which is to determine the election winner according to the NPV election rules, will 
then consist of only the votes cast in the states, where voters cast their ballots for electors from only one of the slates of presidential electors submitted by the candidates competing in the state (as the "winner-take-all" method requires).

Consider an example of such a situation, first published in [57, 33]. Let a state opposing the NPV with, say, seven electoral votes have five presidential candidates on the ballot-Democratic, Republican, Green Party, Libertarian, and Independent. Further, let each state voter be entitled to favor any seven electors of the voter's choice out of the thirty-five state electors. Finally, let the top vote-getters represent the state in the Electoral College. If a state voter chooses two electors from the Republican slate, two electors from the Green Party slate, and one elector from each of the remaining slates, the vote of this voter cannot be fairly tallied in the NPV tally of the votes cast as a vote favoring any presidential candidate.

This vote-favoring several state electors - may or may not affect the composition of the state delegation in the Electoral College. But in either case, (a) any attribution of each such vote to a particular presidential candidate would likely be contested in court, especially in close elections, and (b) the tally of votes favoring presidential electors throughout the country would no longer determine the distribution of support of voting voters for presidential candidates. This would undermine one of the underlying claims of the NPV originators that the NPV compact awards electoral votes controlled by its state-signatories in line with the national popular vote.

Thus, even if only one state opted to oppose the NPV election rules, their introduction may be challenged in court and may require a constitutional amendment. This would obliterate another underlying claim that the plan could be introduced without amending the Constitution [57, 58].

Conducting elections in the described manner in the states protesting against the NPV plan would be a legitimate form of self-defense that the states could exercise to counteract attempts to ignore their opposition to circumventing the Constitution $[33,57,58]$. So, under the Constitution, the states that oppose the NPV plan would not be defenseless against it being forced upon them. The plenary right of state legislatures to choose a manner of appointing state electors - which underlies the NPV plan-is a double-edged sword. In considering such federal issues as changing the rules of presidential elections, this sword can defend the constitutionally guaranteed eligibility of every state to have a say in national elections against divisive attempts to ignore their will [33].

It seems that the NPV originators construe too broadly the constitutionally guaranteed plenary right of a state legislature to choose a manner of appointing state presidential electors. They insist that any such manner can be chosen by the state legislature without any restrictions. If their logic were true, then appointing state presidential electors based upon election results, say, in D.C., or in any state, or even by means of tossing a coin would be legitimate as well.

Only the Supreme Court may decide whether appointing state electors by a collective decision of several state-signatories to the NPV plan is in line with the above-mentioned plenary right. It seems, however, that there is a situation in which 
the NPV idea - to award the electoral votes controlled by the state-signatories based on the tally of all the votes cast for presidential electors throughout the countrymight have a chance to be introduced. It might be the situation in which none of the 50 states and D.C. object, though not necessarily subscribe, to the NPV plan.

If the Supreme Court found such a change of election rules constitutional provided all the states do not object, the NPV proponents could claim success for their plan. That is, they could then claim that they had managed to introduce direct popular presidential elections in the country without amending the Constitution. But even if this were the case, it would still remain unclear (at least to the author) what good the NPV rules can bring to the country.

There is one controversial NPV statement that deserves to be considered, since it seems to be a cornerstone of the NPV plan.

The statement asserts that the states may allow their voters to vote directly for President [5]. This contradicts the Constitution, and the Supreme Court reaffirmed this in Bush v. Gore [59]. The use of the so-called short ballots-in which only the names of the presidential and vice-presidential candidates heading the slates of their electors, rather than the names of the electors themselves, appear-does not attribute any constitutionality to the NPV statement.

Even de facto this could have been true only if state presidential electors from the winning slate had constitutionally been obliged to favor the presidential and vice-presidential candidates heading the slate. However, constitutionally, presidential electors are free agents (see Sect. 2.2), and as such they can favor whomever they want, despite all the restrictions imposed upon them in (currently 29) states and in D.C.

This bears evidence that the statement is questionable to say the least.

\subsection{Is the NPV Plan Constitutional?}

Only the Supreme Court can eventually answer this question. This may happen if (a) the Court decides to consider a case relating to the NPV, and (b) the Court either does or does not find any grounds to conclude that the NPV plan violates the Constitution or any Supreme Court decisions.

Until this happens, one can only speculate regarding the constitutionality of the NPV plan while weighing arguments for and against one of the two potential Supreme Court rulings.

This section presents arguments favoring the viewpoint that the NPV plan may violate some particular provisions of the Constitution and Supreme Court decisions that directly or indirectly relate to presidential elections. These arguments reflect the viewpoint of the author, and unless these arguments are supported or rejected by the Supreme Court, they are no more than logical discrepancies that seem to be present in the NPV plan. 
The author's approach to the analysis of the constitutionality of the NPV plan substantially differs from that of the NPV originators, who assert that the plan is constitutional.

Moreover, the NPV originators and backers assert that even Congress has no reason to consider whether forming a compact of states to collectively decide the election outcome - as the NPV plan does - requires approval of Congress. Though constitutional lawyers are among those who publicly assert this, their assertions are no more than the opinions of their authors that may or may not be supported by Congress and by the Supreme Court.

From the author's viewpoint, the NPV plan faces three major constitutional challenges.

1. The originators of the NPV plan believe that they construe a key provision from Article 2 of the Constitution correctly. That is, the NPV originators believe that the legislatures of a group of states can sign an agreement to collectively award the electoral votes that these states control. Moreover, the originators of the plan believe that the group can award electoral votes in any manner it wants.

2. Formally, the NPV plan does not imply the abolition of the Electoral College. Moreover, the plan involves holding statewide popular elections in which state voters will vote for slates of presidential electors submitted by eligible pairs of presidential and vice-presidential candidates. Legally, these statewide elections are held to identify the winning slate of electors to represent every state in the Electoral College. However, the winning slate may or may not be the one to cast ballots in the Electoral College for state-signatories to the NPV plan. According to the NPV plan, the tally of all the votes cast for electors throughout the country determines which slate of electors will represent each state-signatory to the NPV plan in the Electoral College. If the tally result does not coincide with the will of the voters from any state-signatory, the choice of this state will be ignored.

Thus, the NPV plan puts forth a two-stage procedure to determine which electors will cast ballots on behalf of the states in the Electoral College. At the first stage, the will of state voting voters is detected in the course of a statewide election. At the second stage, this will is either honored or ignored depending on the tally of all the votes cast for presidential electors throughout the country.

Though the NPV originators declare legitimate this quite strange manner of awarding state electoral votes, there is a principle problem with its application. To understand this, consider the case in which slate $\mathrm{A}$ is the winning slate in a state, whereas slate B, the losing slate, is to represent the state in the Electoral College in line with the NPV election rules. Let slate A win the statewide election held to determine the will of the state, and let it win by a majority of the votes cast. If the electors from slate B are to represent the state in the Electoral College, the weight of the vote of every voter who favored slate A in the statewide election becomes smaller than the weight of the vote of every voter who favored slate $\mathrm{B}$. This change of the weights of the votes may violate the Equal Protection Clause from the Fourteenth Amendment, as the Supreme Court has determined several times in cases relating to statewide elections. 
In a state-signatory to the NPV plan, it may even happen that according to the NPV election rules, state electoral votes are to be awarded to a pair of presidential and vice-presidential candidates whose names were not on the ballot in this state at all. If this were the case, under the NPV rules, a slate of electors who were not even voted for in the statewide election may, nevertheless, represent the state in the Electoral College. In this case, the weight of every vote cast in the statewide election would be nullified.

3. State-signatories to the NPV plan may turn out to be the only group of the states prohibiting their voters to favor electors from slates of electors of different presidential candidates competing there. If this is the case, then according to the NPV election rules, votes cast in the other states cannot be counted in the tally that is to determine the fate of a majority of all the electoral votes in play in the election. This may be the case even if the votes cast in all these other states form a majority of all the votes cast in the country.

For instance, let some, say, 20 states and D.C. be signatories to the NPV plan. Further, let ticket A win in each of the 20 states, and let ticket B win in D.C. Also, let the tally of all the votes cast in these 20 states and in D.C. (in favor of (the electors of) all the presidential candidates, including candidates A and B), determine that the margin of votes favoring ticket B in D.C. is such that ticket B receives at least a plurality of votes cast in the 20 states and in D.C. Then ticket $B$ will be declared the election winner according to the NPV election rules.

Finally, imagine a presidential election in which not only does this scenario take place, but also ticket A wins in all the other 30 states. Then had the Electoral College been formed in line with the election rules that have existed in the country for more than two centuries, ticket A would have won the election by a landslide. However, ticket B, which won only in D.C., will be declared the election winner according to the NPV election rules.

One can only imagine how the country will react to such an election outcome, and how many lawsuits contesting the election results and the NPV election rules will be filed.

One may object, which the NPV originators and proponents always do, that some extreme and weird outcomes are possible under any election rules [59]. Also, they may refer to the current system that may engender weird election outcomes as well $[1,18,21]$. However, while such a reference would be correct, the deficiencies of the current system do not justify the introduction of doubtful election rules that have the potential to engender even more extreme election outcomes than the current system may produce. This is especially true when the introduction of the new system is done without the approval of three-fourths of all the states and even without a vote of the country on this new system. 


\subsection{Twisting One Constitutional Right of the State Legislatures}

Article 2 of the Constitution reads “... Each State shall appoint, in such Manner as the Legislature thereof may direct, a Number of Electors...." The originators of the NPV plan assert that these words are "the only guidance" that the Constitution gives to the states on how the states should award their electoral votes. The originators are certainly correct about these words, which guide the states in appointing their electors as the Constitution requires. However, there are other words in the Supreme Law of the Land that impose limits on possible manners that state legislatures may choose in electing state presidential electors. No state alone or a group of states collectively may go beyond these limits other than by means of a constitutional amendment.

Specifically, Section 2 of the Fourteenth Amendment reads "... But when the right to vote at any election for the choice of electors for President and Vice President of the United States... is denied to any of the male inhabitants of such State, being twenty-one years of age, and citizens of the United States, or in any way abridged, except for participation in rebellion, or other crime, the basis of representation therein shall be reduced..." [19]. Besides these words, the Nineteenth and the Twenty Sixth Amendments also contribute to forming such limits.

Section 1 of the Fourteenth Amendment reads “... No State shall make or enforce any law which shall abridge the privileges or immunities of citizens of the United States... nor deny to any person within its jurisdiction the equal protection of the laws...." Thus, the privileges of the citizens residing in the other states should not be abridged by decisions that a state or a group of states can make unless, of course, these decisions become part of a constitutional amendment. In particular, a manner of appointing state presidential electors by any state should not abridge the privilege of any other state to affect the election outcome via its electors.

However, the NPV election rules seem to be an example of such an abridgement. Under the NPV election rules, a state that opts to choose its presidential electors other than by determining the winning slate of electors on the "winner-take-all" basis is effectively excluded from electing a President.

The NPV originators and supporters admit that the chosen manner of appointing state presidential electors should not "violate any specific restriction contained elsewhere in the Constitution" [5]. At the same time, they believe that the legislature of any state may choose a manner of appointing state electors in any way the state legislature "sees fit." Thus, the NPV originators seem to believe that a group of states collectively appointing electors, as the NPV rules propose, does not violate any part of the Constitution.

This doubtful belief is one of the cornerstones of the NPV plan. Moreover, its originators apparently consider themselves pioneers paving the way to a better system and that the states that currently are not among state-signatories to the plan 
will join this plan in the near future. To justify this expectation, the NPV proponents refer to the "winner-take-all" method that the country has come to use via state-by-state piecemeal changes in state laws rather than by means of a constitutional amendment.

Though this remark itself is correct, there is no analogy with the NPV plan. All the states have chosen the "winner-take-all" method for awarding state electoral votes acting on their own, and they did not sign any interstate compact agreements to this end. Moreover, each state decided that the use of such a "state property" as the votes of voting voters cast for slates of its state presidential electors would best reflect the will of the state in electing a President.

In contrast, the NPV plan allows a group of the states to decide the election outcome based on the tally of all the votes cast throughout the country for all the presidential electors in the places where voters vote for slates of electors. This tally is used by the state-signatories to the NPV plan regardless of whether the other states agree or at least do not mind that "their" votes are used in such a manner.

The other reference of the same kind that the NPV proponents make in [5] to justify the above expectation is “... Women's suffrage is another example of state legislatures collectively using the authority granted to them by the U.S. Constitution...," and this analogy is also quite misleading.

By 1919, women did have the vote in 30 of the then 48 states. But, once again, this did not happen as a result of any "compact agreement" between the states. Though a majority of the states then forming the Union already allowed women to vote, only the Nineteenth Amendment gave women the right to vote. The amendment imposed the "women's suffrage" on the minority of (18) states [19] once it was ratified by 36 (out of then 48) states. In any case, the decisions made by an individual state to allow women to vote in the state did not affect the other states in their decisions on this particular matter [1].

Similar observations hold for other examples of "allegedly collective" actions of the states, such as the introduction of direct popular elections of U.S. Senators, which the NPV originators refer to in an attempt to justify their "pioneering mission." This type of election had been used by several states de facto, before the Seventeenth Amendment was adopted and ratified [19]. But as in the previous two references, each state did it on its own, without any compact agreements, and its decision did not affect the other states.

To summarize, the reasoning presented in this paragraph suggests that such a broad interpretation of the plenary right of the state legislatures to choose a manner of appointing state electors as they want, proposed by the NPV originators and proponents, does not seem to have any grounds. Nor does this interpretation have any analogies with other radical changes in the country that have happened in the history of the U.S. The Constitution sets, though not explicitly, certain boundaries within which any state officials can make decisions to let these decisions be acceptable to all the other members of the Union. 


\subsection{Do the NPV Rules Violate the Supreme Court Decisions?}

To answer the question in the section title, one should review (a) the NPV election rules relating to awarding electoral votes in state-signatories to the NPV plan, and (b) the Supreme Court decisions relating to the issue.

The NPV election rules may potentially change the weights of votes of voting voters that are cast in statewide elections to determine the winning slate of electors only in the state-signatories to the NPV plan. Indeed, if a state does not subscribe to the NPV plan and uses the "winner-take-all" method to determine the winning slate of state electors in a statewide election, the NPV rules cannot affect the statewide election result there.

Let us review how electoral votes are to be awarded in the state-signatories to the plan under the NPV election rules by considering a particular state-signatory to the NPV plan in a particular presidential election. For the sake of definiteness, let us consider the 2004 election in Massachusetts [60].

In that election, $36.78 \%$ of Massachusetts voters favored George W. Bush, whereas $61.94 \%$ of the state voters favored John Kerry, a U.S. Senator from Massachusetts [31]. The statewide election in Massachusetts was held to determine the winning slate of presidential electors, and $98.72 \%$ of all the votes cast in the state favored the Democratic and the Republican slates of electors.

The number of votes cast was 2,912,388 [31], and at the time of holding the statewide election, each vote had one and the same weight $1 / 2,912,388$. Under the "winner-take-all" method for awarding Massachusetts' electoral votes, all the 12 electoral votes were awarded to John Kerry.

Had the NPV election rules been in force in the 2004 election, the result in the state of Massachusetts would have been different. Indeed, since all the electors of George W. Bush received more than 3 million votes more than all the electors of John Kerry nationwide, in the hypothetical 2004 election-i.e., in the 2004 election under the NPV election rules - all the Massachusetts electoral votes would have been awarded to George W. Bush. This means that the result of the statewide election in Massachusetts would have been overturned. This would mean that the NPV election rules would give $36.78 \%$ of "Bush" voters more weight than $61.94 \%$ of "Kerry" voters. As a result of applying these rules, the weight of the vote of a "Bush-voter" in Massachusetts would have been made more than 1.68 times greater than that of a "Kerry-voter" in the hypothetical election.

The Supreme Court in Gray v. Sanders stated that “... Once the geographical unit for which a representative is to be chosen is designated, all who participate in the election are to have an equal vote... This is required by the Equal Protection Clause of the Fourteenth Amendment ... The idea that every voter is equal to every other voter in his state, when he casts his ballot in favor of one of several competing candidates underlies many of our decisions..." [61]. In a statewide election held to determine the winning slate of electors, the "representative" is that very slate "to be chosen." So unless the Supreme Court finds that its decision in Gray v. Sanders is 
not applicable to a statewide election in a state-signatory to the NPV plan held under the NPV election rules, these election rules violate this decision. Also, in Bush v. Gore, the Supreme Court stated that "... Having once granted the right to vote on equal terms, the State may not, by later arbitrary and disparate treatment, value one person's vote over another. See e.g., Harper v. Virginia Board Of Electors, 383 U.S. 663, 665 (1966)... once the franchise is granted to the electorate, lines may not be drawn which are inconsistent with the Equal Protection Clause of the Fourteenth Amendment..." [62]. This means that the state legislature cannot hold a statewide popular election under one rule of determining the election winner and then change the election result by applying any different rule that would "value one person's vote over another."

Thus, the NPV election rules may violate both Supreme Court decisions in state-signatories to the NPV plan in which the results of statewide elections held to determine the winning slates of electors do not coincide with the results of tallying the votes cast for all the slates of electors throughout the country. If this is the case, any eligible voter from a state-signatory to the NPV or from D.C. may challenge in court the constitutionality of the NPV election rules that may change the weight of her/his vote in a statewide election of state electors. The Supreme Court decision on Gray v. Sanders, as well as on Bush v. Gore (which refers to Gray v. Sanders) may constitute grounds for such a challenge.

In considering any potential case on the matter of changing the weight of votes in statewide elections held to determine the winning slate of electors, the Supreme Court will need to find whether the election rules proposed in the NPV plan are such that they constitute "... an instrument for circumventing a federally protected right..." [61]. This right is the right of every voter within a state of her/his residence to have an equal vote with all other state voters in any statewide election, reaffirmed by the Supreme Court in Gray v. Sanders.

The same logic that was presented for the state of Massachusetts is applicable to any state-signatory to the NPV plan. Indeed, according to the NPV election rules, a state-signatory to the NPV plan is to hold a statewide election. In this election every voting voter casts a ballot for one of the slates of presidential electors competing in the state, and the same holds for D.C. All the votes cast for all slates of presidential electors throughout the country are tallied to determine the pair of presidential and vice-presidential candidates whose electors received at least a plurality of all the tallied votes. Finally, the state-signatories to the NPV plan award their electoral votes to the winning pair of the candidates, i.e., to the pair of the candidates whose electors received at least a plurality of all the tallied votes (if no tie between two or among more than two pairs of the candidates occurs). If the winning pair of the candidates does not coincide with the pair that heads the winning slate of electors in a state-signatory to the NPV plan, the application of the above NPV election rules leads to changing the weights of votes cast in the state.

Finally, under the current election rules, all the votes cast within any of the 50 states, including the states of Maine and Nebraska, and within D.C. have equal weights. In Maine and in Nebraska, all votes cast within any congressional district of either state have an equal weight, and all the votes cast in either state as a whole 
also have an equal weight within the state (which, however, may differ from that in each congressional district of either state). Thus, under the current election rules, the equality of votes within a state and within D.C. holds in every presidential election.

In contrast, under the NPV election rules, the equality of vote weights holds for D.C. and for the state-signatories to the NPV plan only if the will of the voters there and the results of tallying the votes cast for all presidential electors coincide.

\subsection{An Egregious NPV Rule for Appointing Non-elected Electors}

It may happen that the election winner determined according to the NPV election rules had not been on the ballot in a state-signatory to the NPV plan. The NPV originators call this scenario "hypothesized" and "politically implausible" [5]. However, this may happen under multi-candidate presidential elections if they are held under the NPV election rules in a particular election year. Indeed, a presidential candidate who needs to win, say, only a $20 \%$ plurality of votes to be cast for all the slates of presidential candidates may not be very concerned if she/he is not qualified to be on the ballot in a state-signatory to the NPV or in D.C. [63]. If this were the case for a state-signatory to the NPV, any electors that could be appointed there would be those who had not been voted for by voting voters in the statewide election held to determine the winning slate of state electors there.

It is clear that any reasonable election rules should eliminate such scenarios as those capable of being constitutionally challenged in courts. However, as in many other situations, the NPV election rules do not eliminate them simply because the NPV originators consider such scenarios implausible.

The NPV originators seem to understand how damaging for their cause this scenario would be. Nevertheless, they have not considered the constitutionality of the NPV procedure to be applied should this scenario happen.

At first glance, one may believe that if this scenario were to happen in a state, the legislature of this state would use its plenary right to determine the manner of appointing state presidential electors. In particular, the state legislature could either appoint state electors themselves or would delegate this privilege to the candidate who won the election under the NPV election rules.

Indeed, in Bush v. Gore, the Supreme Court reaffirmed that the power to appoint state electors in any manner can be taken back by the state legislature at any time [62]. However, it is not clear whether the state legislature can do this after holding a statewide election to determine the winning slate of electors. In Reynolds v. Sims the Supreme Court stated that if the state legislature decided to choose "... a manner of appointing state presidential electors, by taking the granted franchise away from the state electorate after the franchise has been freely granted, it would effectively have denied the right of suffrage..." [64] to voting voters. Also, by refusing to appoint electors in line with the results of the above statewide election, the state 
legislature would nullify the weight of every vote cast in this election. This may contradict the Supreme Court decision stated in Reynolds v. Sims in which the Court pointed out that "... the right of suffrage can be denied by a debasement or dilution of the weight of a citizen's vote just as effectively as by wholly prohibiting the free exercise of the franchise..." [64]. At the very least, no “... equal dignity owed to each voter..." [64] will be provided by the state legislature should it choose to ignore the results of the statewide election, contradictory to the requirement of the Supreme Court expressed in its opinion on Bush v. Gore [62].

Though one cannot predict how the Supreme Court might address the issue (if it takes such a case under any circumstances), it is interesting to understand the viewpoint of the NPV originators on the matter.

In addressing the scenario under consideration in this section [5], they submit that "...even in this politically implausible scenario, the National Popular Vote compact would deliver precisely its promised result, the election of the presidential candidate who received the most popular votes in all 50 states and in D.C...."

From this statement, one can see that the NPV originators either do not see the potential legal challenge that this particular NPV election rule may face, or believe that all the above arguments do not have any value in conformity with the NPV rules. They seem to be sure that the NPV election rules will withstand the Supreme Court scrutiny should they be challenged in Court. Also, they seem to believe that the so-called "back-up procedure," which the authors of [5] offer if the scenario were to occur, would resolve the problem in any state-signatory to the NPV in which the winning candidate was not on the ballot. (This procedure consists of allowing the presidential candidate whose (appointed) presidential electors received a plurality of all the votes cast for all the slates of presidential electors nationwide "... to nominate the presidential electors from that state" and allowing “... a state's presidential elector certifying official to certify the appointment of such nominees....")

The considered scenario that may occur under the NPV election rules may be "strengthened" even further. One may wonder: what could happen under the NPV election rules if the winning pair of presidential and vice-presidential candidates were on the ballot in none of the state-signatories to the NPV? The answer is simple: according to the above "back-up procedure" offered by the NPV originators, the winning presidential candidate would nominate presidential electors in all these states, and the so-called presidential elector certifying officials in these states would certify the appointment of such nominees. Thus, according to the NPV rules, the will of all the voters from the state-signatories to the NPV would be ignored, despite the statewide election results in these states.

It seems that the NPV originators believe that they can propose any egregious rules in the set of the NPV election rules and expect them to be adopted, despite any legal challenges that these rules may present. 


\subsection{Does the NPV Plan Really Retain the Electoral College?}

Formally, the NPV plan does not abolish the Electoral College. However, it transforms it into a body in which the state-signatories to the NPV dictate their will to the other states.

The NPV originators make two deceptive statements about their plan.

1. They assert that the NPV compact "would preserve the Electoral College" and that "... It would not affect the structure of the Electoral College contained in the U.S. Constitution...."

2. They also claim that "... Under the National Popular Vote plan, the states would retain their exclusive and plenary right to choose the method for awarding their electoral votes...."

It is hard to believe that the NPV originators do not understand what kind of changes to the Electoral College the NPV plan implies. More likely, these two statements are no more than an attempt to disguise the essence of the NPV plan.

Under the NPV election rules, the Electoral College would remain only as a name for a set of presidential electors who formally elect a President. It would cease to exist as a mechanism for electing a President. Under the NPV rules, 51 members of the Union will no longer form their independent decisions on who are the best candidates to fill the two highest offices in the country.

Instead, the Electoral College will consist of one collective unit, which will always decide the election outcome, and state electors from non-signatory states.

The collective unit will be formed by D.C. and state-signatories to the NPV plan. The states outside this collective unit may become divided into two groups - the states that under the NPV election rules will continue to vote for slates of presidential electors in statewide elections and the states that will not. The will of the states from the second group will simply be ignored, and votes of their voters will not count in the election.

The states from the first group of non-signatory states will play the role of "donors," supplying the NPV tally with votes from their states cast for slates of their state electors. The will of these states may or may not coincide with the decision of the collective unit, but in any case, the electoral votes to be cast by their representatives in the Electoral College will not change the election outcome, no matter which persons they decide to favor. The roles of both groups of the outside states (i.e., the states that are not signatories to the NPV) will be slightly different in the Electoral College under the NPV election rules. However, they will be common in one issue - together they will control only a minority of all the electoral votes in play in the election and will not be able to affect the election outcome.

This will be completely different from how the Electoral College currently operates and will contradict the idea underlying the design of this election mechanism. 
To better understand how the Electoral College will operate under the NPV election rules, one should turn to the theory of voting. From the viewpoint of this theory, under certain assumptions [46, 65], the Electoral College is a so-called weighted voting game, which has been extensively studied [66]. In the framework of this game, participating players (voting units) do not necessarily have the same weight in determining the outcome. Each weighted voting game is set by describing the players, player weights, and the so-called quota of the game. This quota equals the minimum "collective" weight, and any group of the players that manage to control this weight wins in the game.

In the current Electoral College weighted voting game, all the 50 states and D.C. are the players, the player's weight is the number of electors that each state, as well as D.C., appoints in a presidential election. Certainly, the weight of each player does not exceed the number of electors that the state is entitled to appoint in the election according to the Constitution [1, 19]. In this game, the quota equals the number of electoral votes in a minimum majority of all the appointed electors. If each of the 50 states and D.C. appoint as many electors as each of them is entitled to appoint in the election, currently the quota equals 270 electoral votes.

In this game, participating pairs of presidential and vice-presidential candidates compete in each of the 50 states and in D.C. in an attempt to build a coalition of members of the Union that together control at least the quota of the game. To win in the game, a pair of presidential and vice-presidential candidates must win in a coalition of states and D.C. that control at least 270 electoral votes combined.

The pair of presidential and vice-presidential candidates whose electors receive the most votes in a statewide election in each of the states and in D.C. win the electoral votes there. Currently, except for the states of Maine and Nebraska, winning a plurality of votes in a state or in D.C. is sufficient for winning (the number of) all the (electoral) votes that the corresponding state or D.C. has in the weighted voting game. Here it is assumed that all the electors vote faithfully in the Electoral College and do not abstain.

Certainly, if some of the states award their electoral votes not according to the "winner-take-all" method, it may happen that the state may be represented in the Electoral College by electors who are to support different pairs of presidential and vice-presidential candidates. (Such schemes of voting, for instance, for individual electors have been used in the past $[5,6]$.) If this is the case, the number of players in the game will exceed the number of all the members in the Union. Indeed, each individual elector from any state that is not represented in the Electoral College by the only slate of state electors should be considered a separate player.

Generally, due to the manner of using the "winner-take-all" method for awarding electoral votes in the states of Maine and Nebraska, these two states should be considered as several players each. The state of Maine should be considered as three units out of which two units have one (electoral) vote each, and the remaining unit has two (electoral) votes. The state of Nebraska should be considered as four units out of which three units have one (electoral) vote each, and the remaining unit has two (electoral votes). 
For the sake of simplicity, in this section, only 50 states and D.C. are considered players in the Electoral College weighted voting game. Thus, it is assumed that all the states, including the states of Maine and Nebraska, vote in the Electoral College as units, which these two states have done since adopting the Maine-like district scheme for awarding state electoral votes (since 1969 in Maine, and since 1981 in Nebraska; see Sect. 1.3.) The only exception was in the 2008 election, when (the electors of) B. Obama won one electoral vote in one of the three congressional districts in Nebraska [31]. It is also assumed that all the 50 states and D.C. use the "winner-take-all" method for awarding state electoral votes.

The NPV plan offers a different weighted voting game [1]. In this game, D.C. and state-signatories to the NPV plan form a collective player. This player has the weight that is equal to or exceeds the quota of the game, i.e., has the weight of at least 270 (electoral) votes. In the theory of voting, such a player is called a dictator, whereas the players who cannot affect the outcome of the game are called dummies. The outcome in the NPV compact weighted voting game is completely determined by the dictator-i.e., by D.C. and the state-signatories to the NPV plan-based upon the votes supplied by D.C., state-signatories to the NPV, and state-donors from the first group of the outside states in which voters cannot favor electors from the slates of electors of more than one pair of presidential candidates competing in these states.

Thus, the NPV compact transforms the Electoral College weighted voting game into a game between a dictator and a set of dummies some of which may be state-donors. The outcome in this game is always determined by the dictator.

If all the states and D.C. became signatories to the NPV plan, there would be no game. All the states would then act collectively as one unit. However, if not all the states decided to join the NPV plan, only the opposing states would "... retain their exclusive and plenary power to choose the method for awarding their electoral votes...," contrary to what the NPV originators and backers assert in their statement.

\subsection{Can the States Pull Out of the NPV Compact?}

The NPV originators assert that they cannot. However, it is unclear what constitutes grounds for this optimistic assertion.

First, the intent to withdraw from the compact agreement among the state-signatories to the NPV may emerge in any signatory state under the pressure that the voters from this state who voted in a presidential election may put on the state legislature. This may be the case if these voters believe that the application of the NPV election rules have led to an unfair result. It is especially possible if the outcome would have been different (and fair from their viewpoint) if the old Electoral College rules had been applied. 
Second, one should look at the Constitution, federal statutes, and decisions of the Supreme Court relevant to compact agreements to evaluate the chances of such an intent to materialize in any state-signatory to the NPV plan.

Certainly, the analysis to follow makes sense under the assumption that the formation of a compact of state-signatories to the NPV plan (a) is approved by Congress, and (b) is considered constitutional by the Supreme Court.

Let us consider an illustrative example of the situation that is likely to trigger the pullout of a state-signatory to the NPV plan (assuming that the NPV election rules have been adopted and enforced) [1]. Let (a) the electors of both major party candidates receive almost all the votes cast, and (b) the results of the voting be decisive in a hypothetical presidential election such that no recounts can either automatically commence or be required by state or D.C. laws. Also, let D.C. and some 20 states be signatories to the NPV compact.

Further, let in each of the remaining 30 states (a) slates of state presidential electors compete for the right to represent the state in the Electoral College, and (b) the distribution of votes cast determine the winning slate of electors by a substantial margin. Also, let the margins of votes favoring the winning slates be such that the electors of both major party candidates receive the same number of votes in all the 30 states combined.

Finally, let in each of any 10 states from among the above 20 state-signatories to the NPV plan, (a) the margin of votes favoring presidential electors of candidate B constitute 200,000 votes, (b) in each of the other 10 states, the margin of votes favoring presidential electors of candidate A constitute 190,000 votes, and (c) 100,001 votes be the margin of D.C. votes favoring candidate A.

According to the NPV election rules, candidate A becomes the election winner with a one vote margin, and no recounts will be possible in both the 50 states and in D.C. in principle.

In contrast, under the old Electoral College rules, candidate B could have won the election by a landslide. Indeed, candidate B could have won as many as 498 electoral votes, depending on which states remain part of the NPV compact agreement before Election Day. For instance, let seven states with three electoral votes each and any three states with four electoral votes each form the above 10 states favoring presidential electors of candidate A. Further, let candidate A win only in one state with four electoral votes out of the above 30 states. Then candidate A, who is the election winner under the NPV election rules, would have been a recipient of only 40 electoral votes (21 electoral votes from the seven states with three electoral votes each, 12 electoral votes from the three states with four electoral votes each, three electoral votes from D.C., and four electoral votes from a state from among the 30 states).

Everyone even remotely familiar with the politics of American presidential elections can be sure that many voters, especially those who voted in the election, would be outraged and would blame the NPV election rules for delivering such an outcome. However, nothing other than a try to pull out of the compact agreement could be undertaken to change the election outcome if such an outcome occurred. 
Therefore, one can expect that a lot of pressure would be put on state legislatures from state-signatories to the NPV to pull out of the NPV compact.

Now, let us turn to the grounds on which the NPV originators base their belief that the compact agreement among the state-signatories to the NPV plan is binding to the extent that it disallows the compact members to pull out of the agreement after Election Day and before the day in December of the election year when the Electoral College votes.

In [5], the NPV originators refer to a provision of the Impairment Clause of the Constitution (Article I, Section 10, Clause 1) [19], which they site as follows: “... No State shall... pass any... Law impairing the Obligation of Contracts." They also refer to the Supreme Court's materials from Petty v. Tennessee-Missouri Bridge Construction [67], particularly, to the phrase “... A compact is, after all, a contract...," which, however, is not from the Supreme Court decision in the case. This phrase is from the opinion of the dissenting judges in the case, but not from the decision delivered by the Court.

In contrast, the phrase "... The construction of a compact sanctioned by Congress under Art. I, Section 10, cl.3, of the Constitution presents a federal question... Moreover, the meaning of a compact in a question on which this Court has the final say..." is from the Court decision [67]. Moreover, in footnote 4 to the Supreme Court decision, the phrase "... While we show deference to state law in construing a compact, state law as pronounced in prior adjudications and ruling is not binding..." [67]. Both phrases, which are stronger than those from the previous paragraph, seem to suggest that if the NPV compact agreement is recognized as that of federal importance, the state's right to withdraw from this compact after Election Day, but before the Electoral College votes may not be easy to prove. Yet, in the worst case scenario for a state-signatory to the NPV compact that intents to leave the compact this way, there will still be a chance to challenge the binding power.

Indeed, the plenary right of the state legislature to choose a manner of appointing state presidential electors will remain a constitutional provision. This means that even if the interpretation of both the above provision from Article 1 of the Constitution and the Supreme Court words is favorable to the NPV originators, two provisions of the Constitution-Clause 3 from Section 10 of Article I and Clause 2 from Section 1 of Article 2-may be found to be in conflict.

\subsection{Does the NPV Plan Have a Chance?}

Everything depends on what actions the opponents of the NPV plan will undertake in the next few years and whether they will manage to make the case on the constitutionality of the plan before the Supreme Court. This cannot, however, be achieved by any particular individuals or by groups of individuals. The support of the unbiased media and state legislators is an inseparable part of the process of real 
opposition to the NPV plan. The tactic of open discussion of the NPV plan and its alternatives should be used to counteract the tactic of stealth lobbying of state legislators that the NPV originators and backers currently employ in their attempt to succeed.

Unless this happens, in the absence of any organized opposition to the NPV, the chances of the NPV plan to succeed seem quite real, despite all the challenges considered in this chapter. The existing inertia, the lack of understanding of both the NPV plan and the current election system, and the absence of a public figure (or figures) to take the lead and help organize the opposition movement are among the factors contributing to the potential success of the NPV plan.

Filing lawsuits by the opposition to challenge the constitutionality of the NPV plan in courts requires hiring lawyers, which is unlikely to happen without a financial support that the opposition currently does not have. Also, in the absence of any organized opposition, propagandistic efforts of the NPV proponents and the certainty of many believers that the NPV compact is the best system to elect a President may result in forming a compact of states and D.C. underlying the NPV plan. Moreover, the NPV originators and proponents hope to hold presidential elections according to their rules soon. If this happens, it will be quite difficult to reverse.

Indeed, if the NPV plan is introduced, (the electors of) a President elected under the NPV election rules may receive at least a plurality of all the votes cast for presidential electors in the states not opposing the NPV plan though not necessarily subscribing to the plan. If this happened, the chances of the NPV election rules to stay for at least several presidential elections to come would increase dramatically. These chances would be even stronger if the winning candidate received the same number of electoral votes under the NPV election rules that this candidate would have received under the current election rules.

If, however, common sense prevails, and the constitutionality of the NPV plan is challenged in court, two positive outcomes can emerge [1].

If despite all the problems and contradictions to the existing Supreme Court decisions, the NPV plan is found constitutional, new interpretations of the Constitution will inevitably appear. These interpretations will be instructive to all those who study and administer presidential elections. Some long existing questions on unified voting standards throughout the country will inevitably have to be addressed. Among these questions are those regarding different methods for canvassing votes, as well as different equipment for counting votes, that are used in different states. These standards may be found mandatory if the totality of votes cast for slates of presidential electors (a) in 48 states, (b) in D.C., (c) in each of the three congressional districts and at large in the state of Nebraska, and (d) in each of the two congressional districts and at large in the state of Maine are constitutionally recognized as the national popular vote. Currently, since this totality of votes does not have any constitutional status, the voting standard problems may emerge only within the states, as happened in the 2000 election. 
If, however, the NPV plan is found unconstitutional, all the doable alternatives will inevitably surface in the course of the hearings, and these alternatives will be difficult to silence even by the biased media.

Open Access This chapter is distributed under the terms of the Creative Commons Attribution 4.0 International License (http://creativecommons.org/licenses/by/4.0/), which permits use, duplication, adaptation, distribution and reproduction in any medium or format, as long as you give appropriate credit to the original author(s) and the source, provide a link to the Creative Commons license and indicate if changes were made.

The images or other third party material in this chapter are included in the work's Creative Commons license, unless indicated otherwise in the credit line; if such material is not included in the work's Creative Commons license and the respective action is not permitted by statutory regulation, users will need to obtain permission from the license holder to duplicate, adapt or reproduce the material. 